\title{
PASTORAL KONSELING KEPADA REMAJA KRISTEN INDONESIA DALAM MENGHADAPI PERGAULAN BEBAS
}

\section{Agus Sanjaya}

\section{PENDAHULUAN}

Manusia merupakan makhluk sosial yang pertumbuhan dan perkembangan hidupnya bergantung dan dipengaruhi oleh sesamanya dan lingkungan hidupnya. Pertumbuhan dan perkembangan hidup setiap orang tidak hanya dibentuk dan dipengaruhi oleh faktor-faktor dari dalam dirinya sendiri, tetapi juga oleh faktor-faktor dari luar dirinya. Faktor-faktor dari dalam diri seseorang yang membentuk dan mempengaruhi kepribadiannya disebut faktor internal. Sedangkan faktor-faktor dari luar diri seseorang yang membentuk dan mempengaruhi kepribadiannya disebut faktor eksternal.

Manusia Indonesia pada masa kini sudah tidak hidup di dunia yang serba tertutup dan tabu, tetapi pada dunia yang segala sesuatunya serba terbuka dan bebas. Menurut Kunkel yang dikutip oleh walgita bahwa Karakter manusia ditentukan oleh lingkungan di mana dia hidup dan berinteraksi setiap harinya. ${ }^{1}$ Dalam kepribadian remaja yang sedang dalam perkembangan, remaja mengalami perubahan fisik seperti perubahan suara, pertambahan berat badan dan perubahan bentuk tubuh. Sebagai rangkaian dari proses tumbuh dan berkembang yang berkesinambungan di dalam pribadi remaja, maka keadaannya yang ada saat ini sangat mempengaruhi keadaannya yang akan terjadi di masa depan. "Kepribadian yang mantap tercapai bila seluruh aspek kepribadian remaja meliputi antara lain: aspek emosi dan social diperkembangkan orangtua sebaikbaiknya."

Dasar pembentukan dan perkembangan kepribadian remaja bermula dari peran serta orang tua atau keluarga yang kuat, akan memberikan kemampuan bagi remaja dalam menghadapi berbagai rangsangan yang bisa menggangu kestabilan kepribadian seorang remaja. dengan demikian penulis akan membahas tentang Pastoral Konseling Kepada Remaja Kristen Indonesiai Dalam Menhadapi Pergaulan Bebas.

\section{Pengertian Pastoral Konseling}

Kata Pastoral adalah Mengenai kehidupan di susun; mengenai gembala dan kehidupannya ${ }^{3}$; sedangkan ada dua pengertian untuk kata konseling yaitu: 1. Pemberian

\footnotetext{
${ }^{1}$ Walgito, Bimo, Bimbingan Dan Konseling (studi \& karier), (Yogyakarta: C.V Andi Offshet, 2003), 25

${ }^{2}$ Singgih D. Gunarsa dan Yulia Singgih D. Gunarsa, Psikologi Perkembangan Anak dan Remaja, (Jakarta: BPK. Gunung Mulia, 2004), 115

${ }^{3}$ Departemen Pendidikan Nasional, Kamus Besar Bahasa Indonesia Edisi keempat, (Jakarta: Gramedia, 2002), 1.029.
} 
bimbingan oleh yang ahli kepada seorang dengan menggunakan metode psikologi dan sebagainya; pengarahan; 2. Pemberian bantuan oleh konselor kepada konseli sedemikian rupa sehingga pemahaman terhadap kemampuan diri sendiri meningkat dalam memecahkan berbagai masalah; penyuluhan. ${ }^{4}$ Pastoral konseling berhubungan dengan hidup dan kehidupan seorang gembala jemaat dan kehidupan pelayanannya dalam membimbing umat Tuhan dengan firman Tuhan untuk berbalik kepada Tuhan dan mampu memecahkan berbagai masalah atau tantangan iman yang dihadapinya. Pastoral konseling bertujuan untuk mendewasakan umat Tuhan, agar mandiri dalam imannya kepada Tuhan dalam kehidupannya dengan sesama dilingkungannya dan pelayanannya.

J. I. Ch. Abineno menjelaskan bahwa; Istilah Pastoral berasal dari kata Pastor yang dalam bahasa Latin atau bahasa Yunani disebut Poimen, yang berarti gembala. Istilah gembala juga disebut pendeta yang mempunyai tugas sebagai gembala bagi warga gereja atau jemaat Tuhan. Sedangkan kata konseling dari bahasa Inggris kata consult yang artinya meminta nasehat; kata cosole yang artinya menghibur; kata consolide yang artinya menguatkan. ${ }^{5}$ Selanjutnya Aart Van Beek menjelaskan pengertian pastoral konseling secara etimologis, yaitu: (1). Istilah pastoral berasal dari kata pastor dalam bahasa Latin atau dalam bahasa Yunani disebut poimen, yang artinya gembala. $^{6}(2)$. Istilah konseling berasal dari bahasa Latin yaitu kata consulere, yang berarti memberi nasihat. Pastoral konseling sebenarnya bersifat praktis yakni usaha untuk menolong anggota-anggota jemaat didalam persoalan mereka setiap hari. ${ }^{7}$

Pelayanan pastoral konseling dapat diartikan sebagai kegiatan pastor atau gembala atau pendeta untuk menasehati, menghibur dan menguatkan jemaat Tuhan yang terbelenggu dosa dan menghadapi permasalahan didalam hidupnya dengan firman Tuhan, agar memperoleh kekuatan untuk mampu keluar dari masalahnya, dan berubah, bertumbuh imannya kepada Allah di dalam Tuhan Yesus Kristus.

\section{Dasar Alkitab Pastoral Koseling}

Konseling Kristen merupakan proses pembimbingan yang dinamis, karena antara konselor (pendeta/gembala) dan konseli (orang yang dilayani) dituntun dan dibimbing oleh Roh Kudus dan diterangi oleh Firman Tuhan, sehingga konseli dapat dipulihkan, mengalami perubahan dan pertumbuhan iman kepada Allah di dalam Yesus Kristus.

Magdalena Tomatala menjelaskan tentang konseling Kristen yang unik dengan dasar-dasarnya sebagai berikut: ${ }^{8}$

a. Roh Kudus adalah dinamika konseling Kristen, yakni Roh Kudus menuntun konseling Kristen untuk melayani dan sekaligus memulihkan, mengubah serta mendewasakan konseli.

b. Alkitab adalah standar final bagi konseling Kristen yang benar, yakni memberi petunjuk, arah, tuntunan serta hikmat bagi konselor untuk melaksanakan pelayanannya. Alkitab pun sekaligus menerangi, memberi perubahan oleh Roh

${ }^{4}$ Departemen Pendidikan Nasional, Kamus Besar Bahasa Indonesia Edisi keempat..., 725

5 J.I.Ch.Abineno, Pedoman Praktis untuk Pelayanan Patoral, (Jakarta: BPK. Gunung Mulia, tt), 9.

${ }^{6}$ Aart Van Beek, Pendampingan Pastoral, (Jakarta: BPK Gunung Mulia, 2012), 9 - 10

${ }^{7}$ Ch. Abineno, Pengembalaan, (Bandung: Nilakandi, 1967), 12

${ }^{8}$ Magdalena Tomatala, Konselor Kompeten: Pengantar Konseling terapi Untuk pemulihan, (Jakarta: YT Leadership Foundation, 2000), 15. 
Kudus, memperbaiki serta meneguhkan konseli menjadi lebih teguh, serta menuntun kepada hidup berkemenangan dalam Tuhan.

c. Kristus dan kasih-Nya yang kekal adalah fondasi utama konseling Kristen. Kasih Kristus menjadi dasar kekuatan dan hikmat Allah yang mendorong konselor untuk menolong menyelesaikan masalah konseli sebagai manusia berdosa sampai ke akar-akanya.

d. Janji berkat adalah jaminan peneguhan-Nya bagi Konseling Kristen, yakni konseling Kristen diteguhkan oleh janji berkat Allah yang menjadikannya sempurna dalam menyelesaikan dosa dan masalah masa lalu, masa kini serta masa yang akan datang oleh pengorbanan Yesus Kristus (1 Korintus 15:1 - 9; 1 Yohanes $1: 7,9,4: 10)$.

e. Lingkup kerja Konseling Kristen bersifat universal. Maksudnya adalah konseling Kristen dapat diterapkan secara universal di mana dan kapan saja dengan tujuan menyelesaikan masalah manusia secara total dan menyeluruh.

Konseling Kristen merupakan usaha konseli (pendeta/gembala) memberikan pengertian bagi konseli (orang yang bermasalah) untuk memahami pribadinya dan masalah yang dihadapinya berdasarkan firman Tuhan dan tuntunan Roh Kudus, yang memampukan untuk mengambil keputusan dan bertanggungjawab mengatasi dan keluar dari masalah yang dihadapinya. Konseling Kristen unik, karena proses pembimbingan yang dinamis didasarkan pada Firman Tuhan dalam tuntunan Roh Kudus. Maka nasihat, petunjuk, peringatan, teguran, dorongan dan ajaran dari konselor kepada konseli berdasarkan dan bersumber dari Alkitab. Diharapkan agar Roh Kodus menuntun konseli agar mempertimbangkan dan memutuskan untuk berubah, diteguhkan dan bertumbuh imannya kepada Allah di dalam Tuhan Yesus Kristus. Alkitab adalah sumber dan dasar pelayanan pastoral konseling Kristen dan Yesus Kristus sebagai inti pemberitaannya, maka sangat perlu untuk penulis memaparkan dalam tesis ini contoh-contoh pelayanan Pastoral konseling Kristen dalam Alkitab baik Alkitab Perjanjian Lama maupun Alkitab Perjanjian Baru, sebagai berikut:

\section{Pastoral Konseling Dalam Perjanjian Lama}

Musa merupakan salah satu dari para konselor dalam Alkitab. Dalam perjalananya memimpin umat Tuhan di padang gurun, ia mendengarkan dan memberikan keputusan untuk semua keluhan dan permasalahan yang disampaikan kepadanya. Keputusannya dan nasehatnya berguna sebagai penuntun bagi Israel untuk menjalani kehidupan mereka sehari-hari (Keluaran 18:15-16). ${ }^{9}$ Keluaran 18:13-27 menjelaskan tentang Yitro (mertua Musa) menasehati dan menjelaskan kepada Musa cara mendelegasikan tugas dan tanggung jawab kepada pemimpin seribu orang, pemimpin seratus orang, pemimpin lima puluh orang, dan pemimpin sepuluh orang. Para pemimpin yang dipilih dan didelegasikan tugas dan tanggung jawab oleh Musa adalah orang-orang yang cakap dan takut akan Allah, orang-orang yang dapat dipercaya, dan yang benci kepada pengejaran suap.

${ }^{9}$ Stephen Tanuwijaya, Bimbingan Konselor Kristen, (Jakarta: STT Internasional Philadelphia, 2004), 18-19. 
Musa mendengarkan perkataan Yitro dan melakukannya, sehingga para pemimpin yang didelegasi tugas dan tanggung jawab untuk mengadili bangsa Israel sewaktuwaktu, hanya perkara-perkara yang sukar dihadapkan kepada Musa sedangkan perkara yang kecil diadili mereka sendiri.

Samuel dalam 2 Samuel 12:1-25 menjelaskan tentang nabi Natan menegur, memperingatkan, dan menasihati raja Daud yang telah berbuat dosa untuk menutupi dosanya dengan menghamili Batsyeba istri Uria kemudian membunuh Uria dan mengambil Batsyeba istri Uria menjadi istrinya (2 Samuel 11:1-27). Lalu Daud menyesal dan bertobat dari kesalahan yang dilakukannya. Selanjut raja Daud mengungkapkan pengakuan dosa dan pertobatannya kepada Tuhan melalui nyanyian di dalam Mazmur 51:1-21.

\section{Pastoral Konseling dalam Perjanjian Baru}

Stephen Tanuwijaya ${ }^{10}$ mengatakan bahwa; dalam Kitab Perjanjian Baru adalah sejumlah kata-kata bahara Yunani yang berhubungan dengan pengertian "konseling". Secara khusus kita akan melihat surat Rasul Paulus kepada jemaat di Tesalonika. "Kami juga menasehati (parakaleo) kamu, saudara-saudara, tegorlah (nouthetheo) mereka yang hidup dengan tidak tertib, hiburlah (paramutheomai) mereka yang tawar hati, belalah (antechomai) mereka yang lemah, sabarlah (makrothumeo) terhadap semua orang" (1 Tes. 5:14).

- $\quad$ Parakaleo memiliki arti: menasehati, mendorong, mendukung, menghibur (juga Roma 12:1;15:30 dan 2 Korintus 1:4.

- Nouthetheo berarti: memberi pengertian, mengingatkan, menegur (juga Roma 15:14; 1 Korintus 4:14; Kolose 13:16)

- $\quad$ Paramutheomai berarti: menghibur, menguatkan (juga 1 Tesalonika 2:11)

- Antechomai berarti memberi perhatian, memegang teguh, menggenggam erat.

- Makrothumeo berarti bersabar (Matius 18:26,29; Ibrani 6:15; Yakobus 5:7).

Penulis Injil Yohanes memaparkan tentang percakapan Yesus Kristus dengan perempuan Samaria di sumur Yakub (Yohanes 4:1:42). Percakapan ini terjadi ketika Yesus Kristus bersama para murid-Nya meninggalkan Yudea untuk kembali ke Galilea, dan harus melintasi daerah Samaria tepatnya di Sikhar. Ketika Yesus Kristus bersama para rasul-Nya berhenti di sumber Yakub, saat itu juga datang seorang perempuan untuk menimba air. Perempuan ini diperkenalkan penulis Injil Yohanes dengan sapaan perempuan Samaria.

Mengenai inisiatif dalam pelayanan pastoral Konseling Kristen Magdalena Tomatala menjelaskan bahwa pelayanan pastoral Konseling Kristen bertitik dari inisiatif Allah yang oleh kasih-Nya mencari manusia berdosa. Sejak awal, Allah telah menyatakan bahwa Ia sendirilah yang berinisiatif - diawali dengan penciptaan alam raya dan manusia (Kejadian 1:1-31. ${ }^{11}$ Karena sesaat setelah manusia jatuh dalam dosa, Allah yang berinisiatif untuk mencari dan meneguhkan perjanjian keselamatan (Kejadian 3:15)

\footnotetext{
${ }^{10}$ Stephen Tanuwijaya, Bimbingan Konselor Kristen..., 11

${ }^{11}$ Magdalena Tomatala, Konselor Kompeten: Pengantar Konseling terapi Untuk pemulihan, (Jakarta: YT Leadership Foundation, 2000), 17.
} 
bagi umat manusia yang telah dikuasai dosa (Roma 3:23) untuk membebaskan manusia itu dari dosa (Yohanes 3:16).

Inisiatif Allah untuk mencari dan menyelamatkan manusia yang telah dikuasai dosa dan inisiatif Yesus Kristus dalam melayani perempuan Samaria di sumur Yakub, menjadi contoh bagi setiap pastor, gembala, pendeta bahkan setiap pelayan Tuhan, agar berinisiatif dan kooperatif dalam melayani umat Tuhan yang terbelenggu oleh dosa dan yang sedang menghadapi masalah hidup agar kuat dan mampu meninggalkan dosadosanya dan juga menyelesaikan masalahnya.

\section{Fungsi Pastoral Konseling}

Mengenai fungsi pastoral konseling Oliver Mc Mahan menjelaskan bahwa Ada dua fungsi dari pekerjaan gembala yang dijelaskan Alkitab ialah: memelihara dan melindungi kawanan domba gembalaannya. ${ }^{12}$ Alkitab dengan tegas menjelaskan tentang kedua fungsi utama seorang gembala (domba maupun jemaat) yaitu memelihara dan melindungi. Dalam Alkitab Perjanjian Lama Raja Daud menyebut Tuhan sebagai gembalanya yang membaringkannya di padang rumput yang hijau dan membimbingnya ke air yang tenang, (Mazmur 23:1-6). Sedangkan dalam Alkitab Perjanjian Baru, penulis Injil Yohanes menjelaskan tentang Yesus Kristus yang menyatakan diri-Nya sebagai gembala yang baik, dengan menyatakan; ".....Aku datang supaya mereka mempunya hidup dan mempunyainya dalam segala kelimpahan. (Yohanes 10:10b); dan....memberikan nyawanya untuk domba-dombanya; (Yohanes 10:11).

Fungsi pastoral yang seharusnya dilakukan yaitu; (a). Meringankan rasa sakit; (b). Pelayanan penyembuhan; (c). Memperbaiki yang tidak berfungsi; (d). Pemulihan dan rekonsiliasi. (e). Penginjilan; (f). Belas kasihan dalam pelayanan. ${ }^{13}$ Dalam Yehezkiel 34:4, Allah memberikan garis-garis besar mengenai bidang-bidang fungsi pastoral yang spesifik, karena telah diabaikan para gembala Israel. Sedangkan fungsi-fungsi pastoral ini sangat esensial dalam pekerjaan penggembalaan yang seharusnya dikerjakan oleh seorang gembala umat Tuhan. Akibatnya domba-domba berserakan dan terbunuh, karena tidak ada gembala yang memelihara dan melindungi dari bahaya pembunuhan. "Domba-domba-Ku berserak dan tersesat di semua gunung dan di semua bukit yang tinggi; ya, di seluruh tanah itu domba-domba-Ku berserak, tanpa seorang pun yang memperhatikan atau yang mencari (Yehezkiel 43:5-6).

\section{Tujuan Pastoral Konseling}

Manusia adalah makluk sosial yang tindak mungkin melepaskan diri dari huubungannya dengan orang lain atau hidup tanpa sesamanya. Karena selain makluk sosial, manusia juga makluk komunikatif yang butuh orang lain untuk berkomunikasi. Didalam komunikasi manusia dengan sesamanya terjadi dan jalin sosialisasi yang tanpa disadari sudah terjadi kegiatan konseling. Karena didalam proses komunikasi ada tendensi untuk menolong sesama dengan memberikan nasehat dan bimbingan sesuai pengetahuan dan pengalaman yang dimiliki untuk membantunya agar berusaha keluar dari masalahnya dan memperbaiki hidupnya menjadi lebih baik. Maka Gunarsa

\footnotetext{
${ }^{12}$ Oliver Mc Mahan, Gembala Jemaat yang Sukses, (Jakarta: Metanoia, 2002), 3

${ }^{13}$ Oliver Mc Mahan, Gembala Jemaat yang Sukses..., 6
} 
mengungkapkan tujuan konseling menurut George dan Christiani (1981) sebagai berikut: $^{14}$

\section{Menyediakan Fasilitas Untuk Perubahan Perilaku}

Membawa yang bersangkutan agar terjadi perubahan yang memungkinkan kehidupan yang produktif, yang lebih membawa kenikmatan dan kepuasan hidup dengan segala keterbatasan lingkungan hidup. Istilah "milieu therapy" menunjukkan perlunya manipulasi lingkungan sehingga dapat mengubah prilaku.

\section{Meningkatkan Ketrampilan Untuk Menghadapi Sesuatu}

Kehidupan selalu disertai dengan persoalan yang harus dihadapi. Bagaimana menghadapi dan mengatasi persoalan hidup, dibutuhkan kemampuan atau ketrampilan dan juga kemauan untuk menghadapinya.

\section{Meningkatkan Kemampuan Dalam Menentukan Keputusan}

Mengambil keputusan disadari sebagai tindakan yang tidak mudah karena banyak hal yang perlu dipertimbangkan tetapi manusia dihadapkan untuk mengambilm keputusan berulang kali, baik yang ringan dan sederhana maupun yang berat, rumit dan beresiko.

\section{Meningkatkan Hubungan Antar Perorangan}

Sebagai makluk sosial manusia membutuhkan orang lain dari sebab itu guna memenuhi kebutuhan tersebut dibutuhkan kemampuan untuk membina hubungan yang harmonis dengan belajar berusaha untuk saling menyusuaikan diri dan menerima dengan saling menghargai. Konseling bertujuan untuk saling meningkatkan kualitas kehidupan agar mampu menilai diri dan menilai orang lain dengan lebih objektif.

\section{Menyediakan Fasilitas Untuk Mengembangkan Kemampuan}

Tidak perlu diragukan setiap manusia memiliki kemampuan. Firman Tuhan berkata "tiap-tiap orang dikaruniakan pernyataan Roh untuk kepentingan bersama," (1 Korintus 12:7). Seringkali kemampuan tersebut, tidak atau kurang berfungsi dengan berbagai sebab diantaranya tidak menyadarai akan keberadaan kemampuan tersebut di dalam diri kita. Konseling dilakukan dengan harapan agar potensi yang dimilik seseorang dapat digunakan dengan sebaik-baiknya sehingga yang bersangkutan dapat menjalani hidup lebih efektif.

Pelayanan pastoral konseling bertujuan untuk membantu orang lain dalam menghadapi dan keluar dari masalah hidupnya serta mampu mengambil keputusan dalam menentukkan langkah hidupnya, agar menjadi lebih produktif dan lebih menikmati kehidupannya secara realistis karena perubahan pola pikir dan prilakunya.

Gunarsa Singgih mengungkapkan pandangan George dan Christiani (1981) bahwa setelah menganalisa dan mempertimbangkan perumusan-perumusan yang diberikan oleh beberapa pakar konselor dan psikolog dan mereka kemudian mengemukakan beberapa faktor penting yaitu: (a). Konseling berhubungan dengan tujuan membantu orang lain

\footnotetext{
${ }^{14}$ Gunarsa Singgih D., Konseling dan Psikoterapi, (Jakarta: BPK Gunung Mulia, 2000), 23-27.
} 
menentukan pilihan dan tindakannya. (b). Bahwa dalam proses konseling terjadi proses belajar. (c). Bahwa terjadi perubahan dan perkembangan kepribadian. ${ }^{15}$ Karena konseling sebagai usaha dan tindakan untuk memberikan nasehat, bimbingan, motivasi dan semangat oleh konselor, sebagai proses pertumbuhan dan perkembangan pribadi konseli. Dalam hal ini, perlu ditekankan bahwa konseling tidak hanya dimaksudkan untuk keluar dari masalah-masalah hidup saja, namun juga sebagai bimbinganbimbingan untuk hidup mandiri dan melanjutkan kehidupan yang menjadi lebih baik.

Magdalena Tomatala tujuan selengkapnya dari Konseling Kristen dapat diurakan sebagai berikut ${ }^{16}$ :

a. Konseling Kristen bertujuan untuk membawa pemahaman dan penerimaan diri.

b. Konseling Kristen bertujuan untuk membina komunikasi ke arah keterbukaan yang menyiapkan jalan bagi penyembuhan yang dikerjakan oleh Allah.

c. Konseling Kristen bertujuan untuk memberi kemampuan untuk belajar (mendidik), membawa, dan menikmati perubahan yang dari Allah di dalam batin, yang menolong untuk hidup harmonis dengan Tuhan, diri serta orangg lain (Titus 2:11$15)$.

d. Konseling Kristen bertujuan untuk mendukung agar konseli dapat menikmati kehidupan yang berkelimpahan dengan mengaktualisasi diri dalam Tuhan guna tetap bertumbuh menjadi matang dan dewasa (Yohanes 10:10b; Filipi 4:5-8, 13).

e. Konseling Kristen bertujuan untuk menunjang individu konsele untuk bangkit, berjuang bagi tercapainya tujuan hidup dan menang dalam Tuhan (I Korintus 15:58), sehingga konsele menjadi teguh di dalam Tuhan di mana ia mampu hidup mandiri dan berdiri teguh sebagai pemenang (Banding: Roma 8:28-39).

f. Konseling Kristen bertujuan untuk membawa "shalom" Allah yang menyeluruh bagi hidup individu konsele di dalam Tuhan (Yesaya 32:17; Yohanes 14:27; 10:10b; I Petrus 3:8-12), di mana ia bukan saja mengalami pembaruan hidup serta mengalami hidup berkelimpahan, tetapi ia pun menjadi berkat bagi orang lain (Galatia 6:9-10; Efesus 2:10; II Timotius 3:17).

g. Konseling Kristen secara khusus bertujuan untuk meneguhkan konsele untuk hidup berkemenangan oleh roh Kudus sehingga ia menghidupi serta mengekspresikan hidup etis - moral yang memuliakan Allah dan membawa berkat bagi sesama (Efesus 5:15-21; Yohanes 15:26-27).

Dalam proses pastoral konseling, konselor kristen harus tahu bahwa dirinya adalah wakil Tuhan Yesus Kristus, maka harus memposisikan dirinya sebagai pembawa damai sejahtera dari Allah. Maka konselor (pastor/pendeta) bertanggung jawab membawa konsele (jemaat yang dilayani) untuk mengenal dirinya dengan jelas dan seutuhnya melalui terang firman Tuhan dan menerima dirinya seutuhnya dengan penuh ucapan syukur karena totalitas hidupnya adalah anugerah Tuhan. Melalui masalah-masalah yang didalam hidup konsele dapat ditelusuri hubungan pribadinya dengan Allah dan jika belum menerima Yesus Kristus menjadi Tuhan dan Juruselamat pribadi, maka melalui firman Tuhan konsele dituntun untuk menerima Yesus Kristus menjadi Tuhan dan Juruselamat pribadinya. Karena seseorang tidak menerima Yesus Kristus menjadi Tuhan

\footnotetext{
${ }^{15}$ Gunarsa Singgih D., Konseling dan Psikoterapi..., 21

${ }^{16}$ Magdalena Tomatala, Konselor Kompeten: Pengantar Konseling terapi Untuk Pemulihan, (Jakarta: YT Leadership Foundation, 2000), 20.
} 
dan Juruselamat pribadinya, maka tidak akan memperoleh anugerah keselamatan dari pada Allah dan Roh Kudus juga akan bekerja di dalam hidupnya sehingga tidak berhasil di dalam hidupnya.

\section{Masa Remaja}

Pada bagian penulis akan memaparkan beberapa hal yang berkaitan dengan Masa Remaja.

\section{Pengertian Masa Remaja}

Istilah "remaja" berasal dari bahasa Latin yaitu kata "adolescere" (kata bendanya adolescentia) yang berarti remaja atau "tumbuh" atau "tumbuh menjadi dewasa". 17 Maka istilah remaja pada umumnya dikenal sebagai masa peralihan dari masa kanakkanak ke masa dewasa. Perubahan yang beranjak dari masa kanak-kanak, yang dimulai dengan semburan pertumbuhan pubertas dan didorong oleh perubahan hormonal masa pubertas, untuk mencapai hak prerogatif, tanggungjawab dan kemandirian.

Mengenai pengertian remaja, maka John W. Santrock menjelaskan bahwa meskipun rentang usia dari remaja dapat bervariasi terkait dengan lingkungan budaya dan historisnya, kini di Amerika Serikat dan sebagian besar budaya lainnya, masa remaja dimulai sekitar usia 10 hingga 13 tahun dan berakhir pada sekitar usia 18 hingga 22 tahun. $^{18}$ Sedangkan F. J. Monks dan A. M. P. Knoers yang memberi batasan usia remaja adalah 12 - 21 tahun. Dengan pembagian 12 - 15 tahun adalah masa remaja awal, 15 - 18 tahun adalah masa remaja pertengahan, 18 - 21 tahun adalah masa remaja akhir. ${ }^{19}$ Masa remaja adalah masa transisi atau masa peralihan diantara masa kanakkanak dengan masa dewasa. Jadi secara status, remaja tidak jelas statusnya di masyarakat, karena remaja tidak termasuk golongan kanak-kanak, juga tidak termasuk golongan orang dewasa. Dari sisi fungsi, remaja belum mampu untuk menguasai fungsifungsi fisik maupun psikisnya, sehingga digolongkan sebagai kanak-kanak, namun bila diamati dari pertumbuhan fisiknya sudah dewasa.

Menurut penjelasan Elizabeth B. Hurlock bahwa secara umum remaja dibagi menjadi dua bagian, yaitu awal masa remaja dan akhir masa remaja. Garis pemisah antara awal masa remaja dan akhir masa remaja terletak kira-kira disekitar usia tujuh belas tahun; usia saat mana rata-rata setiap remaja memasuki sekolah menengah tingkat atas. ${ }^{20}$ Sesuai penjelasan tersebut maka dapat dikesimpulkan bahwa masa remaja adalah masa usia 12 - 21 tahun. Pada masa usia 12 - 21 tahun seseorang sedang mengalami masa peralihan dari masa kanak-kanak ke masa dewasa. Salah satu kriteria pada masa remaja adalah pertumbuhan fisik yang cepat baik dari dalam maupun dari luar, dan mengakibatkan terjadinya perubahan sikap, perilaku, kesehatan, serta kepribadiannya.

Masa remaja dipahami sebagai masa transisi antara masa kanak-kanak dengan masa dewasa. Pada masa ini remaja mengalami banyak perubahan (fisik, psikologi, emosi, sosial, intelektual dan rohani). Masa transisi ini merupakan masa yang sangat

17 Elizabeth B. Hurlock, Psikologi Perkembangan suatu Pendekatan Sepanjang Rentang Kehidupan, edisi kelima, (Jakarta: Erlangga, 1980), 206 - 209.

18 John W. Santrock, “Remaja Jilid 1”, (Jakarta: Erlangga 2007), 20

${ }^{19}$ F. J. Monks dan A.M.P. Knoers..., 262, 259

${ }^{20}$ Elizabeth B. Hurlock..., 206 
sulit, dimana seseorang meninggalkan masa kanak-kanak dan beralih (proses menuju) masa dewasa. Masa remaja adalah masa dimana seorang remaja mencari-cari jati diri, masa yang penuh dengan ingin mencoba sesuatu/atau hal-hal yang baru atau yang penuh dengan tantangan. Masa remaja merupakan masa yang indah, tetapi tidak masa juga masa yang rawan karena merupakan masa transisi/masa peralihan. Biasanya remaja mengalami keadaan/kondisi krisis, kawatir, kecewa, bahkan penuh dengan keraguraguan.

Menurut Erikson yang mengatakan bahwa; "Masa remaja seringkali dikenal dengan masa mencari jati diri, ini disebut dengan identitas ego. Ini terjadi karena masa remaja merupakan peralihan antara masa kehidupan anak-anak dan masa kehidupan orang dewasa. Ditinjau dari segi fisiknya, mereka sudah bukan anak-anak lagi melainkan sudah seperti orang dewasa tetapi jika mereka diperlakukan sebagai orang dewasa ternyata belum dapat mewujudkan sikap dewasa". ${ }^{21}$ Jadi masa remaja merupakan persimpangan antara masa kanak-kanak dengan masa dewasa, karena pada masa remaja seseorang sedang mencari identitas dirinya, karena belum mengenal dirinya dengan benar karena sedang dalam pertumbuhan. Karena itu, masa remaja selain dikatakan di persimpangan juga lebih dikenal dengan masa peralihan dari masa kanakkanak ke masa dewasa, yang dalam perkembangannya ditandai dengan proses kematangan (fisik, psikologi, emosi, sosial, intelektual dan rohani).

\section{Perkembangan Masa Remaja}

Perkembangan masa remaja menjelaskan tentang perubahan-perubahan yang dialami seorang remaja dalam tahapan hidupnya. Berbicara tentang tahapan kehidupan manusia tentu harus membahasnya secara komprehensif yaitu mulai masa kanak-kanak, masa remaja, masa dewasa dan masa tuanya. Pikunas (1976) dalam kutipan Hendriati Agustiani mengemukakan beberapa tugas perkembangan yang penting pada periode pertengahan dan akhir masa remaja. Secara umum tugas perkembangan masa remaja berkaitan dengan dirinya sendiri dan juga dengan lingkungan sosial yang dihadapinya. ${ }^{22}$ Pada masa ini remaja mulai berhadapan dengan aspek-aspek kehidupan yang abstrak yang menimbulkan dugaan-dugaan dan pertanyaan-pertanyaan yang muncul dari benaknya sendiri. Pada bagian ini pembahasan hanya difokuskan pada tahapan perkembangan remaja sebagai berikut:

\section{Perkembangan Fisik Remaja}

Perkembangan yang paling menonjol dalam pertumbuhan seorang remaja adalah perkembangan fisik. Mengenai perkembangan fisik remaja, maka J. Edward Hakes menyatakan bahwa: "Secara jasmani tubuhnya menunjukkan ciri-ciri dan potensi kedewasaan, tetapi penggunaan potensi ini kurang bijaksana. Kehidupan emosionalnya telah mencapai puncaknya namun kebudayaan membatasi dia dalam mengungkapkan perasaannya. Norma-norma yang harus dipatuhi yang berkaitan dengan penyesuaian diri dan harapan orang dewasa sangat membingungkan si remaja dari segi sosial ia sedang

\footnotetext{
${ }^{21}$ Muhammad Ali dan Muhammad Asrori, Psikologi Remaja, (Jakarta: Bumi Aksara, 2005), 16

${ }^{22}$ Hendrianti Agustiani, Psikologi Perkembangan (Pendekatan Ekologi Kaitannya dengan Konsep Diri dan Penyesuaian diri pada Remaja..., 6
} 
melepaskan diri dari ikatan orangtua dan memihak generasinya sendiri."23 Jadi ciri-ciri khusus pada perkembangan secara fisik, pertumbuhan fisik remaja bertambah besar dan tinggi. Terutama remaja laki-laki lebih tinggi dan berat badannya tambah, pada usia ini remaja laki-laki biasanya mengejar remaja perempuan yang sama-sama mengalami pertumbuhan. Pada masa ini remaja laki-laki memiliki nafsu makan yang berlebihan, sedang remaja perempuan sudah mulai memperhatikan penampilannya. Pada fase inilah anak remaja mengalami hambatan pembinaan dan pertumbuhan iman, karena sudah mulai mengenal lawan jenis, menjaga penampilan, mempunyai komunitas sendiri dan berusaha menentukan pilihan berhubungan dengan pribadinya.

Dalam membahas pertumbuhan fisik pada remaja dan akibatnya, maka Elisabth B. Hurlock menyatakan bahwa: "Bagi sebagian besar anak muda, usia antara 12 dan 16 tahun merupakan tahun kehidupan yang penuh kejadian sepanjang menyangkut pertumbuhan dan perkembangan. Tak dapat disangkal selama kehidupan janin dan tahun pertama atau kedua setelah kelahiran, perkembangan berlangsung semakin cepat dan lingkungan yang semakin lebih menentukan, tetapi yang bersangkutan sendiri bukanlah remaja yang memperhatikan perkembangan atau kurangnya dengan kagum, senang atau takut". ${ }^{24}$ Dari penjelasan ini dapat dipahami bahwa dalam perkembangan fisik kaum remaja terjadi begitu cepat, dan pada fase ini remaja juga secara wajar sedang mempersiapkan atau memantapkan dan membentuk perkembangan fisiknya melalui kebiasaan-kebiasaan yang lakukannya, diantaranya kebiasaan yang baik maupun yang buruk. Oleh sebab itu sebagai akibat dari sikap teladan orang yang tidak baik, remaja akan mencoba-coba menghisap rokok, minum alkohol dan obat bius sehingga itu yang menjadi akibat dari teladan orang dewasa yang tidak baik, selera jasmani dan pengaruh teman-temannya.

Dadang Sulaiman menjelaskan bahwa; "Salah satu ciri penting dalam perkembangan pada masa remaja adalah terjadinya perubahan-perubahan jasmani yang menimbulkan akibat yang bermacamm-macam: (1). Mereka harus menyesuaikan dirinya dengan perubahan-perubahan proporsi badannya. (2). Secepat mereka tampak seperti orang dewasa dalam besar dan bentuk tubuhnya, secepat itu pula mereka diharapkan dengan tuntutan-tuntutan baru. Semakin tampak mereka seperti orang dewasa, mereka dituntut untuk bertindak lebih dewasa, sekalipun mungkin mereka tidak mempunyai cukup waktu untuk belajar serta menemukan dirinya dalam peranan-peranan yang baru itu. (3). Reaksi para remaja terhadap perubahan-perubahan jasmaniah tersebut bermacam-macam. Ada yang menerimanya dengan perasaan bingung dan takut-takut". ${ }^{25}$ Proses penyesuaian terhadap perubahan-perubahan fisik oleh remaja, dipersulit lagi dengan kenyataannya bahwa dirinya tidak dapat meramalkan apakah matang lebih cepat atau lambat, karena ada di antara remaja yang sudah "matang" pada usia 12 tahun, sedangkan temannya baru pada usia 14 atau 15 tahun. Jadi usia kematangan remaja tidak dapat dipastikan, karena ada yang cepat, tapi juga ada yang lambat.

${ }^{23}$ Hendrianti Agustiani, Psikologi Perkembangan (Pendekatan Ekologi Kaitannya dengan Konsep Diri dan Penyesuaian diri pada Remaja...,

${ }^{24}$ Elisabth B. Hurlock, Psikologi Perkembangan, (Jakarta: Erlangga, 1980), 207

${ }^{25}$ Dadang Sulaiman, Psikologi Remaja, (Bandung: Mandar Maju, 1995), 23 


\section{Perkembangan Mental Remaja}

Setelah perkembangan fisik, perkembangan remaja berikutnya adalah perkembangan mental remaja. Perkembangan yang paling berpengaruh dalam perkembangan mental remaja adalah perkembangan prilaku dan intelektual yang cukup tinggi. Menurut Mery Go Setiawani yang menyatakan bahwa; "Sifat kritis anak tunas remaja sekarang berubah menjadi pertimbangan yang baik. Sekarang ia lebih berperan dalam masyarakat pada waktu pemikirannya, pengawasan diri, sifat berdikari, dan pandangan menjadi lebih luas." ${ }^{26}$ Pengaruh intelektual remaja sangat mempengaruhi pertumbuhan dan perkembangan mentalnya. Walaupun demikian, namun pertimbangannya masih belum matang, daya pikirannya sedang berkembang dengan cepat dan sudah bisa berpikir dengan memecahkan masalah-masalah yang sulit. Daya khayal remaja mencapai tingkat yang tinggi dan menjadi dasar bagi idamannya untuk mencapai prestasi ke depan.

Dalam perkembangan mental remaja yang masih labil, remaja teropsesi dengan sebuah profesi yang digemarinya, oleh karena itu remaja butuh pembimbingan kristen, agar opsesinya terhadap profesi yang idamkannya tidak menjadi cela penghambat bagi pembinaan dan pertumbuhan iman. Remaja butuh saran-saran dari orangtua, pembina remaja di gereja dan guru Pendidikan Agama Kristen di sekolah.

Menurut M. Daliono yang menyatakan bahwa; "Umur remaja mempengaruhi kapasitas mentalnya." 27 Mental remaja sangat mempengaruhi pertumbuhan intelektualnya, karena pada usia ini prestasi belajarnya mengalami pertumbuhan ke tingkat kematangan. Dengan demikian, maka para remaja harus dapat menyalurkan energi, keprihatian dan potensi dirinya melalui berbagai kegiatan yang dapat memacunya untuk menunjukkan kemampuan dan pertumbuhan mental dan intelektualnya yang makin bertambah.

\section{Perkembangan Emosi Remaja}

Mengenai perkembangan emosi remaja, maka menurut Elisabeth B. Hurlock, yang menyatakan bahwa; "Remaja 14 tahun seringkali mudah marah, mudah dirangsang dan emosinya cenderung "meledak", tidak berusaha mengendalikan perasaannya. Sebaliknya remaja 16 tahun mengatakan bahwa mereka tidak punya keprihatinan". ${ }^{28}$ Ciri emosi pada permulaan masa remaja ialah mudah marah, mudah dirangsang, emosinya cenderung meledak dan tidak berusaha mengendalikan perasaannya. Sebaliknya usia akhir masa remaja ciri-cirnya ialah tidak mempunyai keprihatinan.

Selanjutnya Mary Go Setiawani menyatakan bagwa; "Selain itu usia ini juga memiliki perasaan yang suka membedakan dan menyukai pengalaman yang bermacammacam. Perkembangan emosi pada di usia ini, ditandai dengan emosinya". ${ }^{29}$ Walaupun emosi remaja seringkali sangat sulit untuk dikendalikan dan tampaknya irasional atau tidak masuk akal, namun pada umumnya semakin stabil seiring bertambahnya usia menjelang dewasa menjadi lebih tenang dan menguasai diri.

\footnotetext{
${ }^{26}$ Mery Go Setiawani..., 88

${ }^{27}$ M. Daliono, Psikologi Pendidikan, (Jakarta: Rineka Gipta, 2005), 73

${ }^{28}$ Elisabeth B. Hurlock..., 213.

${ }^{29}$ Mary Go Setiawani..., 91
} 
Elisabeth B. Hurlock menyatakan bahwa; "Remaja mengenakan banyak rangsangan yang tadinya dapat menimbulkan emosi: akhirnya remaja yang emosinya matang memberikan reaksi emosional yang stabil tidak berubah-ubah. Ditambahkan pula bahwa untuk mencapai kematangan emosi, remaja harus belajar tentang bagaimana memperoleh gambaran situasi-situasi yang dapat menimbulkan reaksi emosional". 30 Agar remaja cepat mengalami kematangan emosi, maka harus ada objek baginya untuk menyalurkan emosinya tersebut. Cara yang tepat adalah remaja diberikan berbagai latihan fisik yang berat seperti; masuk kelompok-kelompok olah raga, masuk sanggarsanggar kesenian, masuk kelompok-kelompok pelatihan ketrampilan dan berbagai kegiatan lainnya sehingga emosi remaja tersalurkan, maka remaja tidak akan menjadi liar untuk mengendalikan gejola emosi.

\section{Perkembangan Sosial Remaja}

Perkembangan sosial remaja juga perlu diperhatikan, karena pada usia ini remaja membutuhkan pengembangan diri dalam bersosialisasi. Menurut Sumadi Surybrata yang mengutip pendapat Montessori yang menyatakan bahwa; "Usia 12-18 tahun adalah penemuan diri dan kepekaan rasa sosial". 31 Untuk seorang remaja menemukan identitas dirinya, remaja tersebut harus mengembangkan diri melalui kemampuan untuk bersosialisai. Sebab melalui bersosialisasi, remaja akan menemukan identitas dirinya. Kemudian ditambahkan dengan mengutip pendapat Kohnstamm (1990) yang mengemukakan bahwa; "Periodisasi umur kira-kira 13 atau 14 sampai kira-kira 20 atau 21 tahun disebut masa sosial, periode usia remaja ini melalui perkembangan sosial". 32

Selanjutnya Elisabeth B. Hurlock menyatakan bahwa; "Diiringi juga dengan bertambahnya minat yang cenderung membentuk kelompok serta mengadakan kegiatankegiatan kelompok sosial". ${ }^{33}$ Usia remaja lebih cenderung beradaptasi dengan teman sebayanya dengan membentuk komunitas-komunitas, sebagai wadah mengembangkan diri, untuk menemukan identitas dirinya itu. Dengan demikian, maka sangatlah penting bagi remaja untuk diberikan kesempatan untuk dan membangun hubungan dan berpartisipasi dalam berbagai kelompok sosial di masyarakat.

Dalam proses perkembangan sosial remaja, untuk belajar menyesuaikan diri dengan lingkungannya, baik di keluarga, di sekolah, maupun lingkungan di masyarakat, maka Singgi D. Gunarsa dan Y. Singgih d. Gunarsa mengutip pandangan A. A. Schneiders yang mengemukakan mengenai penyesuaian diri sebagai berikut: "Bahwa penyesuaian diri merupakan suatu proses mental dan tingkah laku yang mendorong seseorang untuk menyesuaikan diri sesuai dengan keinginan yang berasal dalam diri sendiri, yang dapat diterima oleh lingkungannya". ${ }^{34}$ Jadi penyesuaian diri remaja adalah reaksi seorang remaja terhadap rangsangan-rangsangan dari dalam dirinya sendiri maupun reaksi orang lain terhadap situasi yasng berasal dari lingkungannya. Jadi perkembangan sosial individu remaja, sangat tergantung pada kemampuan individu

\footnotetext{
${ }^{30}$ Elisabeth B. Hurlock..., 213

${ }^{31}$ Sumadi surybrata, Psikologi Pendidikan, (Bandung: Raja Grafindo Persada, 2002), 189

${ }^{32}$ Ibid., 193

${ }^{33}$ Elisabeth B. Hurlock..., 29

${ }^{34}$ Singgi D. Gunarsa dan Y. Singgih d. Gunarsa..., 93-94
} 
remja untuk menyesuaikan dirinya dengan lingkungannya serta keterampilan mengatasi masalah yang dihadapinya.

\section{Perkembangan Rohani Remaja}

Melihat perkembangan rohani anak remaja tidak semuanya sama, disebabkan oleh pembinaan untuk membangun hubungan iman remaja dengan Allah di dalam Tuhan Yesus Kristus berbeda-beda. Oleh karena itu, remaja membutuhkan kemauan dengan mempunyai tujuan yang jelas, menyerahkan hidupnya kepada Allah di dalam Tuhan Yesus Kristus.

Pertumbuhan rohaninya sering terjadi dengan pesat, untuk itu remaja memerlukan pimpinan yang menonjol. Bentuk kepemimpinan ini tidak bersifat menguasai tetapi memberi kesempatan kepada kaum muda untuk bertanggung jawab atas keputusannya sendiri dalam hal-hal rohani. Eli Tanya memberikan beberapa tugas mengenai penguraian dan perkembangan seorang remaja dengan menyatakan sebagai berikut: (1). Mencari identitas diri yang belum stabil (terkadang menganggap diri dewasa, terkadang masih anak-anak). (2). Meletakkan dasar kemandirian yang sehat. (3). Menerima diri dan menghargai diri sendiri. (4). Mengembangkan kemampuan emosional dan intelektual. (5). Memenuhi kewajiban social. (5). Mencari kebebasan emosional dari orangtua dan dewasa lainya. (6). Mempersiapkan diri untuk berkeluarga dan pekerjaan. (7). Mengembangkan sistem etik dan nilai-nilai sebagai pedoman hidup dan filsafat hidup". ${ }^{35}$ Melalui pembinaan iman, remaja diberikan kesempatan untuk belajar bertanggungjawab dan mengambil keputusan dalam hal-hal rohani, agar remaja dilatih untuk menjadi stabil di dalam identitas diri, belajar mandiri, menghargai dirinya sendiri, mengembangkan emosi dan intelektual. Selanjutnya membangun hubungan dengan orang lain, mengendalikan emosinya, mempersiapkan diri bekerja dan berpegang pada firman Tuhan sebagai pedoman hidupnya.

Menurut Robert J. Havighurst yang dikutip Eli Tanya menjelaskan bahwa: “Gereja pada umunya, dapat menolong remaja dengan mendampingin perjalanan sepanjang hidupnya untuk menjadi orang Kristen yang baik dalam arti etis dan kualitatif dengan memenuhi tugas-tugas tertentu dari perkembangan kehidupan remaja." ${ }^{36}$ Remaja butuh pembinaan iman oleh orangtua, guru rohani di gereja dan guru Pendidikan Agama Kristen di sekolah, untuk menolong remaja menemukan kualitas hidupnya sebagai anggota tubuh Kristus, dalam membangun gereja Tuhan di dunia.

\section{Perkembangan Intelektual Remaja}

Pengertian kata intelektual disini berhubungan dengan kata intelegensi. Istilah intelegensi tidak muda dirumuskan karena setiap ahli merumuskan hal yang sama untuk istilah tersebut. Intelegensi hanya memberikan gambran mengenai apa yang tercakup dalam pengertian intelagensi. Singgih D.Gunarsa mengatakan:" intelegensi merupakan suatu kumpulan kemampuan seseorang yang memungkinkan memperoleh ilmu pengetahuan dan mengamalkan ilmu tersebut dalam hubungan dengan lingkungannya

\footnotetext{
${ }^{35}$ Eli Tanya, Gereja dan Pendidikan Agama Kristen, (Jakarta: Sekolah Tinggi Teologi Cipanas, 1999), 70

${ }^{36}$ Eli Tanya, Gereja dan Pendidikan Agama Kristen..., 69
} 
dan masalah-masalah yang timbul." 37 Kemampuan kegiatan intelektual mulai berkembang untuk menangkap arti fundamental suatu objek atau esensi di mulai pada remaja. Seorang remaja tidak akan puas dengan cara melihat suatu objek dari luarnya saja. Karena itu remaja akan mulai ambil jarak ukuran agar bisa menemukan jawabnya, yaitu dengan mengajukan berbagai pertanyaan, seperti mengapa sehingga perbuatan itu berbentuk demikian?.

C.A Van Peursen menjelaskan bahwa: Remaja akan mencari alasan, sebab, artinya serta tujuan dan fungsi dari suatu objek penyelidikannya dan akhirnya bisa memberikan suatu kesimpulan yang logis adalah kecenderungan intelektual remaja dan oleh C.A Van Peursen disebut, "corak berfikir ontologis." 38 Salah satu ciri-ciri pertumbuhan intelektual remaja ialah keinginan untuk mengetahui tentang banyak hal sangat tinggi. Oleh karena itu, perlu untuk memberikan perhatian ekstra bagi seorang remaja pada masa pertumbuhan dan perkembagan intelektualnya agar terarah dan terkontrol dengan baik dan benar.

\section{Perkembangan Psikoseksual Remaja}

Salah satu perkembangan remaja yang sangat perlu untuk dipahami ialah perkembangan psikoseksual remaja. Masa remaja adalah suatu tahap kehidupan yang bersifat peralihan dan tidak mantap. Selain itu, masa remaja adalah masa yang rawan oleh pengaruh-pengaruh negatif, seperti narkoba, kriminal, dan kejahatan seks. Perubahan dan perkembangan pada masa remaja ditandai dengan munculnya tandatanda sekunder dan mulai matangnya organ-organ reproduksi. Menurut Sigmund Freud yang dikutip Kaplan dan Sadock yang menjelaskan bahwa masa remaja sebagai fase genital, yaitu energi libido atau seksual yang pada masa pra remaja bersifat laten kini hidup kembali. Dorongan seks dicetuskan oleh hormon-hormon androgen tertentu seperti testosteron yang selama masa remaja ini kadarnya meningkat. Tidak jarang mereka melakukan masturbasi sebagai cara yang aman untuk memuaskan dorongan seksualnya, kadang-kadang mereka melakukan sublimasi terhadap dorongan seksualnya kearah aktifitas yang lebih bisa diterima, misalnya kearah sastra, psikologi, olah raga atau kerja sukarela, sistem sosial yang memadai sering membantu remaja menemukan cara-cara yang dapat menyalurkan energi seksualnya pada aktivitas atau peran yang lebih bisa diterima. ${ }^{39}$ Dorongan seksual remaja merupakan anugrah Tuhan, yang akan muncul dan bertumbuh pada saatnya. Dengan demikian, sangat perlunya proses edukasi yang benar dan pendampingan pada masa pertumbuhan remaja sehingga tidak bertindak memuaskan atau mengatasi masalah seksual yang dialaminya. Para orangtua harus memiliki pengetahuan seks yang cukup dan tidak menganggap tabu untuk mengedukasi anak-anak remajanya tentang alat-alat seks pada tubuh, pemanfaatannya dan waktu untuk memanfaatkannya agar tidak berakibat buruk. Karena sejak fase remaja pertengahan perilaku dan pengalaman seksual sudah menjadi kelaziman. Dari waktukewaktu remaja makin dini melakukan aktivitas seksual. Baru pada masa remaja akhir remaja mulai ada perhatian terhadap rasa kasih sayang sesama manusia, moral, etika,

\footnotetext{
${ }^{37}$ Singgih D. Gunarsa, Psikologi Remaja, (Jakarta BPK Gunung Mulia, 1984), 70.

${ }^{38}$ C.A.Van Peusen, Strategi Kebudayaan, (Jakarta: BPK Gunung Mulia, 1976), 66.

${ }^{39}$ Kaplan \& Sadock, Sinopsis Psikiatri jilid 1, terjemahan oleh Widjaja Kusuma, (Jakarta: Bumi Putra Aksara, 1997),
} 
agama, dan remaja mulai memikirkan masalah-masalah dunia. Jelasnya citra tubuh, minat berkencan, dan perilaku seksual pada remaja sangat dipengaruhi oleh perubahan pada masa kematangan fisik dan seksual terjadi secara pesat terutama pada awal masa remaja.

Menurut Hurlock yang menjelaskan tentang perkembangan remaja bahwa; Jika ditinjau dari sisi perkembangan, minat remaja terhadap perilaku seks didorong oleh meningkatnya keingintahuan remaja tentang seks. Remaja mencari berbagai macam informasi yang terkait dengan seks melalui bacaan, teman sebaya, atau mengadakan percobaan dengan melakukan masturbasi, bercumbu, atau bersenggama. ${ }^{40}$ Berbagai temuan dari hasil penelitian yang menggambarkan tentang perubahan pola perilaku seks remaja yang terjadi karena perubahan pola heteroseksualitas yang baru di kalangan remaja.

Contoh: Pasangan remaja saat ini, yang melakukan ciuman pada saat kencan pertama, sudah dianggap sebagai sesuatu yang lazim. Padahal pasangan remaja pada masa dahulu, berciuman pada saat berkencan merupakan aib yang merusak hubungan laki-laki dan perempuan yang baru mulai. Karena akan dapat menimbulkan rasa malu dan bersalah bila terjadi dalam kehidupan pasangan remaja yang berkencan. Sedang pasangan remaja saat ini melakukan ciuman saat berkencan, menganggapnya benar dan normal, atau paling sedikit diperbolehkan. Bahkan hubungan seks sebelum nikah dianggap hal yang lazim jika dilakukan dengan rasa cinta. Remaja-remaja saat ini, berhubungan seksual yang dilakukan dengan kasih sayang lebih diterima daripada bercumbu hanya sekedar melepas nafsu.

Adapun tahapan-tahapan menuju sex bebas yang dilakukan pasangan remaja yang sedang berpacaran ialah: (1). Dimulai dengan pegangan tangan; (2). Ciuman sebatas pipi dan kening; (3). Ciuman bibir; (4). Berpelukan; (5). Kemudian mulai berani melepas pakaian bagian atas; (6) Meraba bagian yang sensitive; dan (7) Hingga terakhir melakukan hubungan seks. ${ }^{41}$ Pasangan remaja pada saat berpacaran berani melakukan tahapan-tahapan seks bebas tersebut, karena pengaruh dari pergaulan bebas lingkungannya. Pergaulan bebas yang melewati batas seperti dugem, minum-minuman keras dan sebagainya akan berujung pada seks bebas. Karna pergaulan bebas dapat menyebabkan seseorang lupa diri, merasa tidak modern jika tidak mengikuti tren yang akan berujung pada seks bebas.

\section{Pergaulan Masa Remaja}

Pada bagian penulis akan memaparkan beberapa hal yang berkaitan dengan Pergaulan Masa Remaja.

\footnotetext{
${ }^{40}$ Hurlock, Elizabeth, Psikologi Perkembangan Suatu Pendekatan Sepanjang Rentang Kehidupan, (Jakarta: Erlangga, 1980), 226.

${ }^{41}$ http://sitisalmah27.blogspot.co.id/2014/03/makalah-seks-bebas-dikalangan-remaja.html
} 


\section{Pengertian Pergaulan}

Kata pergaulan dari kata dasar gaul yang berarti campur. Kemudian kata gaul ditambahkan imbuhan per dan an, sehingga menjadi kata pergaulan yang berarti kehidupan bermasyarakat yang mempengaruhi kepribadian. ${ }^{42}$

Pergaulan merupakan jalinan hubungan sosial antara seseorang dengan orang lain yang berlangsung dalam jangka relatif lama sehingga terjadi saling mempengaruhi satu dengan lainnya. Pergaulan merupakan kelanjutan dari proses interaksi sosial yang terjalin antara individu dalam lingkungan sosialnya. Kuat lemahnya suatu interaksi sosial mempengaruhi erat tidaknya pergaulan yang terjalin. Seorang anak yang selalu bertemu dan berinteraksi dengan orang lain dalam jangka waktu relatif lama akan membentuk pergaulan yang lebih. Beda dengan orang yang hanya sesekali bertemu atau hanya melakukan interaksi sosial secara tidak langsung.

Dalam kehidupan sosial ada berbagai bentuk pergaulan, ada yang sehat ada pula yang dikategorikan pergaulan yang tidak sehat. Pergaulan sehat adalah pergaulan yang membawa pengaruh positif bagi perkembangan kepribadian seseorang. Sebaliknya pergaulan tidak sehat mengarah kepada pola perilaku yang merugikan bagi perkembangan dirinya sendiri maupun dampaknya bagi orang lain.

Interaksi sosial asosiatif merupakan interaksi yang sifatnya persekutuan. Interaksi seperti ini biasanya memicu terbentuknya persatuan atau integrasi sosial. Proses Asosiatif adalah suatu bentuk interaksi sosial yang bisa meningkatkan hubungan kesolidaritasan sesama manusia. Interaksi sosial yang bersifat asosiatif, yakni yang mengarah kepada bentuk - bentuk asosiasi (hubungan atau gabungan) seperti : kerja sama, akomodasi / penyesuaian, asimilasi dan akulturasi.

Interaksi sosial disosiatif merupakan bentuk interaksi sosial yang sifatnya memisahkan atau menerapakan proses oposisi. Interaksi disosiatif lebih mengarah pada upaya untuk melawan seseorang atau kelompok untuk tujuan tertentu. Proses disosiatif adalah bentuk interaksi sosial yang dapat merenggangkan/menyempitkan hubungan solidaritas antar individu. Interaksi sosial yang bersifat disosiatif, yakni yang mengarah kepada bentuk - bentuk pertentangan atau konflik, seperti : persaingan, kontravensi dan konflik.

Pergaulan yang sehat adalah pergaulan yang mengarah kepada pembentukan kepribadian yang sesuai dengan nilai dan norma sosial, kesusilaan dan kesopanan yang berlaku.

\section{Pergaulan Bebas}

Kata bebas memiliki beberapa pengertian diantaranya yaitu: (1). Lepas sama sekali dari (tidak terhalang, terganggung, dan sebagainya, sehingga dapat bergerak, berbicara, berbuat dan sebagainya dengan leluasa. (2). Tidak terikat atau terbatas oleh aturan dan sebagainya dan sebagainya. ${ }^{43}$

Pergaulan bebas adalah salah bentuk perilaku menyimpang yang melewati batas dari kewajiban, tuntutan, aturan, syarat, dan perasaan malu. atau pergaulan bebas dapat

${ }^{42}$ Departemen Pendidikan Nasional, Kamus Besar Bahasa Indonesia Edisi keempat, (Jakarta: Gramedia, 2002), 421

${ }^{43}$ Departemen Pendidikan Nasional, Kamus Besar Bahasa Indonesia Edisi Keempat, (Jakarta: Gramedia, 2002), 153-154 
diartikan sebagai perilaku menyimpang yang melanggar norma agama maupun norma kesusilaan. Seperti yang telah disampaikan di atas, pergaulan adalah merupakan proses interaksi antara individu atau individu dengan kelompok. Sedangkan bebas adalah terlepas dari kewajiban, aturan, tuntutan, norma agama dan norma kesusilaan. Pergaulan berpengaruh terhadap pembentukan kepribadian seorang individu baik pergaulan positif atau negatif.

\section{Ciri-ciri Pergaulan Bebas}

Pergaulan Bebas dapat diketahui dengan beberapa cirri-ciri yang menandakan nya antara lain sebagai berikut :

a. Penghamburan harta untuk memenuhi keinginan sex bebasnya

b. Rasa ingin tahu yang sangat besar

c. Terjadi Perubahan-perubahan emosi, pikiran, lingkungan pergaulan dan tanggung jawab yang dihadapi

d. Terjerat dalam pesta hura-hura dengan menggunakan obat-obatan terlarang, seperti ganja, putau, ekstasi dan minuman keras.

e. Menimbulkan perilaku munafik dalam masyarakat

f. Perilaku yang tidak baik

g. Pakaian agak terbuka atau minim

h. Mudah mengalami kegelisahan, tidak sabar, emosional, selalu ingin melawan, rasa malas, perubahan dalam keinginan, selalu menunjukkan eksistensi dan kebanggaan diri serta selalu ingin mencoba banyak hal.

\section{Faktor Penyebab Pergaulan Bebas}

Hal yang terjadi dalam pergaulan bebas banyak bertolak belakang dengan aturanaturan dan norma-norma dalam etika pwergaulan, hal ini disebabkan oleh banyak factor -faktor penyebab antara lain :

a. Rendahnya tarah pendidikan keluarga. Rendahnya tarah pendidikan keluarga yang berpengaruh besar sebagai penyebab terjadinya pergaulan bebas, contohnya keluarga mengizinkan sang anak untuk berpacaran dan ditambah tanpa adanya pengawasan yang menyebabkan anak terjerumus dalam pergaulan bebas.

b. Keadaan keluarga yang tidak stabil. Keadaan keluarga sangat berpengaruh pada tingkah laku atau perkembangan psikis remaja yang mana keadaan orangtua yang tidak harmonis yang membuat perkembangan psikis anak terganggu dan anak cenderung mencari kesenangan di luar, melupakan hal yang terjadi dikeluarganya.

c. Orangtua yang Kurang Memperhatikan. Tidak diperhatikan oleh orangtua yang sibuk dengan pekerjaaannya sehingga anak kurang mendapatkan perhatian yang menyebabkan anak bebas dalam beraktivitas

d. Lingkungan Setempat Kurang Baik. Lingkungan sekitar merupakan factor pembentuk kepribadian seseorang, jika dilingkungan tersebut merupakan lingkungan yang kurang kondusif maka sang anak akan terjerumus kedalam pergaulan bebas

e. Kurang Berhati-hati dalam Berteman. Teman dapat menuntun kita kearah yang positif dan negative dimana sebagian besar pergaulan bebas terjadi karena berteman dengan orang yang kurang baik. 
f. Kurangnya Kesadaran Remaja. Kurangnya kesadaran remaja merupakan implikasi dari kurangnya pengetahuan remaja tersebut akan dampak pergaulan bebas.

\section{Akibat / Dampak Pergaulan Bebas}

Terjadinya pergaulan bebas memberikan pengaruh besar baik bagi diri sendiri, orangtua, masyarakat dan juga Negara, dampak dari pergaulan bebas adalah sebagai berikut :

g. Seks Bebas

Seks bebas adalah dua orang yang berhubungan suami istri tanpa ikatan pernikahan sampai kepada kehamilan diluar nikah, yang tentu saja membuat malu diri sendiri, orang tua,dan keluarga

h. Ketergantungan Obat

Dari ajakan teman karena pikiran yang masih labil, menggiringnya dan ketergantungan obat-obatan terlarang hingga berlebihan dan berdampak over dosis.

i. Menurunya Kondisi Kesehatan

Pergaulan bebas dapat menimbulkan berbagai penyakit seperti HIV AIDS dan banyak yang menggugurkan kandungan yang tentu saja membahayakan hidupnya.

j. Meningkatkan Kriminalitas

Bahaya Pergaulan bebas yang satu ini dapat terjadi karena jika pecandu narkoba tidak lagi memiliki uang untuk membeli, maka yang cepat adalah dengan melakukan tindakan kriminalitas.

k. Meregangkan Hubungan Keluarga

Pergaulan bebas dapat mereggangkan hubungan antara keluarga karena beberapa penyebab yang biasanya karena emosi yang meledak-ledak dan bahkan sampai rasa hormat kepada orang tua bisa hilang.

1. Menurunnya Prestasi

Seorang dengan pergaulan bebaslebih cenderung bersenang dan dapat menghilangkan konsentrasi belajar akibat dari minuman keras dan narkoba.

\section{Pergaulan Bebas di Guangzhou}

Semakin berevolusi budaya China, menyebabkan semakin berevolusinya kegiatan seksual di negara ini. Ingin bukti? Hanya dalam tempo 8 tahun, 5000 toko penyedia perlengkapan dan kebutuhan seks telah berdiri dan hanya berdiri di satu kota, yaitu Beijing ditambah China memiliki SEXPO, dimana warga China datang untuk memeriksa perlengkapan seksnya. $70 \%$ produk seks dunia adalah buatan China, Untuk hal-hal yang telah disebutkan maka China masuk dalam daftar. ${ }^{44}$

Berdasarkan informasi dan pengamatan penulis selama di Cina, rata-rata keluarga di Guangzhou hanya memiliki satu anak saja. Orangtua terlalu sibuk bekerja sehingga anak mereka dititipkan ke kakek dan neneknya. Itulah sebabnya mereka sangat dimanja dan apapun yang mereka minta pasti dikabulkan dan dituruti. Bahkan dalam bergaul pun, orangtua sama sekali tidak membatasi dan melarang anak-anak mereka. Dan itu kemudian berdampak kepada mereka hingga usia remaja.

\footnotetext{
${ }^{44}$ http://pergaulanbebas1990.blogspot.co.id/2011/12/march-18th-2011-negara-negara-dengan.html
} 
Itulah sebabnya pada usia remaja mereka sudah bebas berpacaran, bahkan dalam bus, MRT, mereka bebas berpelukan dan berciuman. Bahkan mayoritas di usia remaja mereka sudah merokok. Kemudian di setiap universitas dibagikan alat kontrasepsi (kondom) kepada setiap mahasiswa. Karena pihak kampus pada dasarnya mengetahui bahwa mahasiswanya banyak yang melakukan hubungan seks di luar nikah. Supaya tidak hamil, maka sekolah mengambil tindakan preventif dengan membagikan alat kontrasepsi (kondom).

\section{KESIMPULAN}

Berdasarkan acuan pada kajian teoritik, hasil penelitian dan pembahasan hasil penelitian sesuai dengan fokus dan sub fokus, maka peneliti memberikan kesimpulan sebagai berikut:

Pertama, ditemukannya kelemahan model pelayanan pastoral konseling terhadap remaja Kristen Indonesia. Hamba Tuhan / pendeta sebagai gembala yang bertanggung jawab atas jemaatnya, tidak konsen terhadap pelayanan pastoral konseling, ini ditandai kurang dipersiapkannya pemimpin komsel yang ditugaskannya untuk memimpin dan membimbing remaja dengan ilmu-ilmu konseling sedangkan remaja sangat membutuhkan bimbingan atau pendampingan agar mereka tidak terpengaruh oleh pergaulan bebas. Oleh karena itu pemimpin komsel kurang memahami tentang pengertian konseling, khususnya konseling Kristen sehingga pemimpin komsel tidak memberikan pemahaman yang benar dan membimbing dengan maksimal remaja Kristen.

Kedua, keterbatasan waktu yang dimiliki oleh pemimpin komsel atau konselor dalam memberikan pembimbingan dan perhatian kepada remaja, mengakibatkan remaja terpengaruh oleh ajakan teman dan lingkungan sekitar sehingga mereka pergi dan menikmati pergaulan bebas.

Ketiga, konselor atau pemimpin komsel belum mempersiapkan model pastoral konseling dan bahan-bahan pembimbingan yang cocok dan sesuai untuk digunakan dalam pembimbingan agar dapat dipahami dan diterima oleh remaja sehingga mereka mampu dalam menghadapi pergaulan bebas. 
Abineno, J. L Ch

\section{DAFTAR PUSTAKA}

nd Pedoman Praktis untuk Pelayanan Patoral, Jakarta: BPK Gunung Mulia

Abineno, J. L. Ch

1967 Pengembalaan, Bandung: Nilakandi

Abineno, J. L. C

2004 Percakapan Pastoral, Jakarta: BPK. Gunung Mulia

Bakar, Abu

2005 Psikologi perkembangan, Jakarta: Studi Press

Beek, Aart Van

2012 Pendampingan Pastoral, Jakarta: BPK Gunung Mulia

Brubaker, J. Oemar dan Robert E. Clark

1972 Memahami Sesama Kita, Malang; Gandum Mas

Campbell, Alastair V

1987 A Dictionary of Pastoral Care, New York: Crossroad

Clinebell, Howard

2002 Tipe-Tipe Dasar Pendampingan dan Konseling Pastoral, Jakarta: BPK

Gunung Mulia

Daliono, M

2005 Psikologi Pendidikan, Jakarta: Rineka Gipta

Enung, Fatimah

2006 Psikologi Perkembangan, Bandung: Pustaka Setia

Gunarsa, Singgih D

2000 Konseling dan Psikoterapi, Jakarta: BPK Gunung Mulia

Gunarsa, Singgih D

1984 Psikologi Remaja, Jakarta: BPK Gunung Mulia

Hall, Callvin S. \&Lindzey

1985 Introduction to Theories of Personality, New York: Gardner, 
Hendriati, Agustiani

2009 Psikologi Perkembangan (Pendekatan ekologi Kaitannya dengan Konsep diri dan penyusuaian diri pada Remaja), Bandung: Rafika Aditama

H. Prayitno dan Andi, Erman

2015 Dasar-dasar Bimbingan dan Konseling, Jakarta: Rineka Cipta

Hurlock, Elizabeth B

1980 Psikologi Perkembangan suatu Pendekatan Sepanjang Rentang Kehidupan, Jakarta : Erlangga

Kaplan \& Sadock

1997 Sinopsis Psikiatri jilid 1, Jakarta: Bumi Putra Aksara

Mc Mahan, Oliver

2002 Gembala Jemaat yang Sukses, Jakarta: Metanoia

Mulyiono, Bambang

1993 Mengatasi Kenakalan Remaja, Yogyakarta: Andi

Muhammad Ali dan Asrori, Muhammad

2005 Psikologi Remaja, Jakarta: Bumi Aksara

Mulyana, Deddy

2002 Metodologi Penelitian Kualitatif Paradigma Baru Ilmu Komunikasi dan Ilmu Sosial Lainnya”, Bandung: PT Remaja Rosdakarya

Monks, FJ \& Knoers, AMP, Haditono

1999 Psikologi Perkembangan Pengantar Dalam Berbagai Bagiannya, (Yogyakarta: Gadjah Mada University Press

Moleong, Lexy J

2010 "Metode Penelitian Kualitatif”, Bandung: PT Remaja Rosdakarya

Nana, Syaodih Sukma Dinata

2004 Landasan Psikologi Proses Pendidikan, Bandung: PT. Remaja Rosda Karya

Peusen, C.A. Van

1976 Strategi kebudayaan, Jakarta: BPK Gunung Mulia

Petualang, Bocah

2008 "Factor-Faktor Pembentuk Karakter". Www.Yahoo, Com, 18 September 
Putra, Nusa

2013 Penelitian Kualitatif IPS, Bandung: PT Remaja Rosdakarya

Santrock, John W

2007 “Remaja Jilid 1, ” Jakarta: Erlangga

Sarliti Wirawan, Sarwono

2007 Psikologi Remaja, Jakarta: Raja Grafindo Persanda,

Singgih D. Gunarsa dan Yulia

2004 Psikologi Perkembangan Anak dan Remaja, Jakarta: BPK. Gunung Mulia

Syamsul, Yusuf LN

2008 Psikologi Perkembangan Anak dan Remaja, Bandung: PT Remaja Rosdakarya

Sogur, Alex

$2003 \quad$ Psikologi Umum, Bandung: Pustaka Setia

Sumadi, Suryabrata

2015 Psikologi Kepribadian, Jakarta: Raja Grafindo Persada

Sulaiman, Dadang

1995 Psikologi Remaja, Bandung: Mandar Maju

Surybrata, Sumadi

2002. Psikologi Pendidikan, Bandung: Raja Grafindo Persada.

Susabda, Yakub B

2014 Konseling Pastoral, Pendekatan Koseling Pastoral Berdasarkan Intgrasi Teologi dan Psikologi, Jakarta: BPK Gunung Mulia

Susabda, Yakub B

1997 Pastoral Konseling Buku Pegangan Untuk Pemimpin Gereja \& Konselor Kristen, Malang: Gandum Mas,

Susabda, Yakub B

2007 Menjadi Konselor Yang Profesional, Sebuah Panduan untuk mereka yang terbeban Menjadi Konselor Kristen yang Profesional, Yogyakarta: Andi

Tanya, Eli

1999 Gereja dan Pendidikan Agama Kristen, Jakarta: Sekolah Tinggi Teologi Cipanas 
Tanuwijaya, Stephen 2004 Bimbingan Konselor Kristen, Jakarta: STT Internasional Philadelphia

Tong, Stephon 2008

Arsitek Jiwa I, Surabaya: Momentum

To'u, Tulus

2007 Dasar-dasar Konseling Pastoral: Panduan bagi Pelayanan Konseling Gereja, Yogyakarta: Andi

Vardiansyah, Dani

2008 Filsafat Ilmu Komunikasi: Suatu Pengantar, Indeks, Jakarta

Walgito, Bimo 2003 Bimbingan Dan Konseling (studi \& karier), Yogyakarta: C.V Andi

Walter R. Borg and Gall, Meredith D

1989 "Educational Research: AnIntroduction, FifthEdition", NewYork: Longman 